\title{
Design and Practice of Integrated Business English Course Based on POA and SPOC Mode
}

\author{
Wang Shanshan \\ English Department, School of Foreign Languages \\ Dalian Neusoft University of Information \\ Dalian, PRC \\ wangshanshan@neusoft.edu.cn
}

\author{
Zhang Yi \\ English Department, School of Foreign Languages \\ Dalian Neusfot University of Information \\ Dalian, PRC \\ zhangyi@neusoft.edu.cn
}

\begin{abstract}
The importance of ESP (English for Specific Purposes) teaching has attracted the attention of more and more scholars since the globalization asks an increasing need for interdisciplinary talents who can make international communication in working environment. Due to condensed contents and limited teaching hours, ESP teaching effectiveness is dissatisfying. The paper tries to apply Production-oriented Approach (POA) to the teaching of ESP based on SPOC environment and has made oneyear teaching practice in the course of Integrated Business English. This paper takes a unit as example to show how the procedures including motivating, enabling and assessing work in SPOC environment. With this paper, the author wishes to present a new way of teaching ESP.
\end{abstract}

Keywords—POA; SPOC; Motivating; Enabling; Assessing

\section{INTRODUCTION}

With the development of Belt and Road Initiative, languages play increasingly important roles in bridging different cultures, business exchange and international communication. Among all the languages, English serves as the most frequently used lingua franca apparently. Consequently, talents with good English proficiency, professional knowledge and cross-cultural communication ability are in urgent need. One way to meet this need better is to improve the teaching effectiveness of English for Specific Purposes (ESP) teaching. While due to the condensed content and limited teaching hours of ESP courses, many ESP teachers focus on language usages introduction only while pay less attention to practice under professional environment. The teaching effect is not satisfying.

Both Production-oriented Approach (POA) and SPOC (small private online course) learning mode are applied by Chinese college teachers in order to improve English teaching effects. POA is proposed by Professor Wen Qiufang, taking "learning-centred principle" as its core. It advocates the design and practice of teaching should target at assuring effective learning, and avoid the separation of learning and application [1]. SPOC is a new blended learning mode. It possesses MOOC's advantage of flexibility, and also keeps the feature of inter-person communication which is a typical advantage of traditional classroom teaching practice [2]

Neither POA nor SPOC is frequently used in ESP teaching. Thus, the author tries to apply them in the design and practice of Integrated Business English Course, a typical ESP course, and wishes to find a way to improve teaching effects.

\section{POA AND SPOC MODE}

Proposed by Professor Wen, POA derives from her outputdriven hypothesis and output driven-input enabled hypothesis. POA puts emphasis on the unity of learning and application [3]. It takes learning output as drive and target, while knowledge input is regarded as an enabling method. According to POA, the complete teaching activity consists of three procedures:

(1) Motivating: the teacher designs appropriate communication scenario and communication-worthy tasks. These task intends to stimulate students' interest in learning.

(2) Enabling: the teacher provides input materials to students and guides students to get necessary knowledge to complete the task.

(3) Assessing: the teacher assesses the task output made by students and gives make-up learning suggestions to students who do not reach the learning objectives [4].

POA needs teachers to design communication scenario and tasks as drives for students. This principle accords the teaching targets of ESP courses, which trains students for the purpose of communication within professional environment in English. This explains why POA could provide new direction in ESP teaching.

Professor Armando Fox of the University of California, Berkeley proposed the conception of SPOC mode in 2013. In this term, the words "small" and "private" intends to show differences from the words "massive" and "open" in MOOC (massive open online course). In other words, SPOC mode set limitation in student number and access to the course. It is a new blended learning mode combining online learning and traditional class-room learning. On one hand, this mode motivates students' self-study drives with sufficient online learning materials; one the other hand, it keeps the in-class interaction between teachers and students, which will give students direct feedback and instruction during study. It could be a good supplement to POA in teaching design. 


\section{DESIGN AND PRACTICE OF INTEGRATED BUSINESS ENGLISH}

Integrated Business English Course is a core course for Business English majors of Dalian Neusoft University of Information, in their first two years in college. This course consists of 4 stages: Integrated Business English 1-4. In this course, language is regarded as the channel and media of communication and topics related to business and cultures perform as the content of communication. In other words, this course takes materials on business and cultures as teaching content, intending to provide language training as well as business and cross-culture communication knowledge input. Taking students' knowledge structure and study capacities at different stages into consideration, the ratios of language, business and cultures vary at different stages of this course, as well. In the preliminary stage, language occupies the largest percentage, while in the later stages, the percentage of business and culture increases.

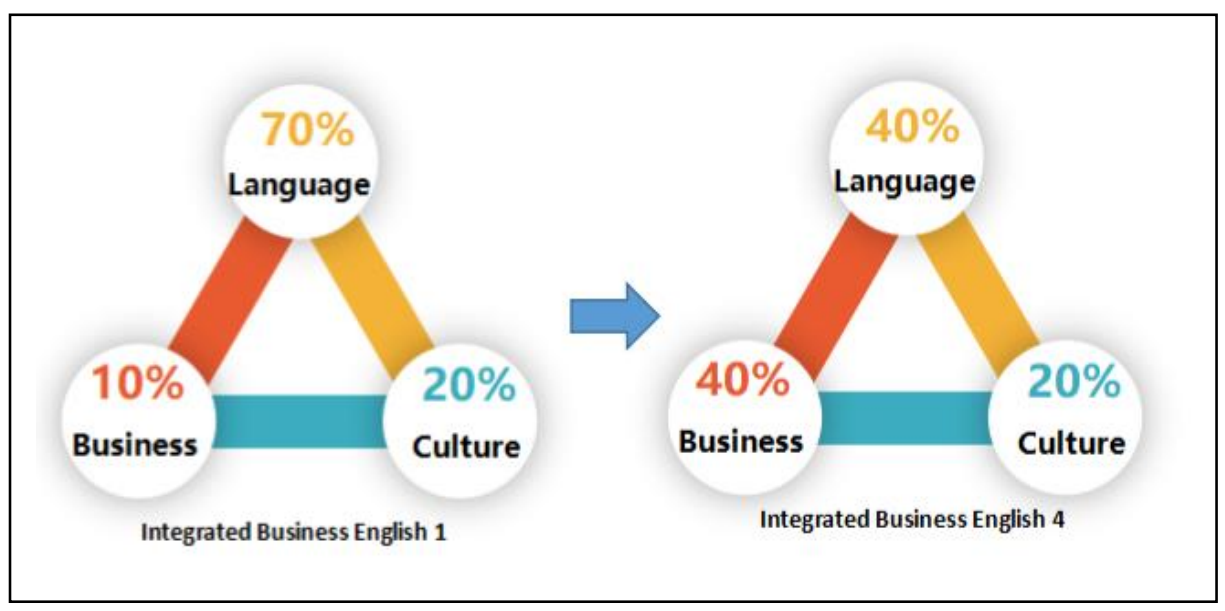

Fig. 1 Knowledge structure of integrated business English

This paper will take Unit 1 Dress for Success of Integrated Business English 1 as example to show the design and practice of a complete unit.

\section{A. Teaching Objectives}

Unit 1 Dress for Success of Integrated Business English 1 focuses on the topic of dressing code in working environment. By learning this unit, students are supposed to reach the following objectives:

- language: to remember the Chinese meaning of 63 new words in this unit, and can pronounce them correctly; to understand the English explanation of 44 words out of the 63 new words and could use 36 words skillfully; to be able to communicate fluently on the topic of Dress for Success; to be able to comprehend passages on dressing code at the speed of 100 words/minute.

- Business: to understand the dressing rules in business environment; to be able the explain the dressing ban of medicine and education industry.

- Culture: be able to tell and explain the business dressing rules in different cultures.

\section{B. Design and Practice}

The teaching procedure is divided into 3 phases: motivating, enabling and assessing:

1) Motivating: directed by the unit teaching objectives, the teacher publishes the motivating task via SPOC platform and organizes students to make the initial trial for the task. Meanwhile, the teacher collects the questions and problems that students find out when making the initial trial Then, the teacher guides students to make self-diagnosis and to think what input they need in order to accomplish this task. By creating a sense of hunger for knowledge, the teacher successfully arouses the learning interest of students. 


\begin{tabular}{|c|c|c|}
\hline Step & \multicolumn{2}{|c|}{ Details } \\
\hline $\begin{array}{l}\text { Step } 1 \\
\text { Publish Task }\end{array}$ & \multicolumn{2}{|r|}{$\begin{array}{l}\text { As the editor of } V O G U E \text {, the fashion magazine, student A has made interview appointments with } 4 \\
\text { guests, and is supposed to give professional suggestion on how they should dress in the interview. } \\
\text { The identities of } 4 \text { guests are: } \\
\text { Student B: a famous doctor of traditional Chinese medicine; student C: a famous American surgeon; } \\
\text { student D: a Chinese professor; Student E: an American professor. } \\
\text { Student A need to send a suggestion outline to the guests respectively via emails and then make calls to } \\
\text { communicate with guests one by one orally. }\end{array}$} \\
\hline $\begin{array}{l}\text { Step } 2 \\
\text { Initial Trial }\end{array}$ & \multicolumn{2}{|r|}{$\begin{array}{l}\text { Student A: is supposed to take a guest as example, and make suggestion on his/her dressing style in the } \\
\text { interview. } \\
\text { Student B, C, D, E: based on the allocated identity, design one's own dressing style in the interview. }\end{array}$} \\
\hline \multicolumn{3}{|c|}{$\begin{array}{l}\text { 2) Enabling: this part is made up with online procedure } \\
\text { (based on SPOC platform) and off-line procedure (based on } \\
\text { class-room activities). During the online enabling } \\
\text { procedure, students are supposed to select and learn the } \\
\text { online materials via SPOC platform based on the self- } \\
\text { diagnosis. The SPOC platform also provides various tests } \\
\text { to help students figure out the necessity of learning a } \\
\text { TABLE II }\end{array}$} \\
\hline \multicolumn{2}{|c|}{$\begin{array}{l}\text { Step } 2 \\
\text { Group Discussion }\end{array}$} & $\begin{array}{l}\text { Students of the whole class are required to leave their original groups and set up new teams: } \\
\text { All the student As will group into Team A, and students with identities of B, C, D, E will set up Team } \\
\text { B, C, D and E as well. } \\
\text { Team A: make group discussion on the main content of the email. } \\
\text { Team B: make group discussion on the dressing rules and bans of doctors of traditional Chinese } \\
\text { medicine } \\
\text { Team C: make group discussion on the dressing rules and bans of American doctors. } \\
\text { Team D: make group discussion on the dressing rules and bans of Chinese professors } \\
\text { Team E: make group discussion on the dressing rules and bans of American professors }\end{array}$ \\
\hline $\begin{array}{l}\text { Step } 3 \\
\text { Script Writing }\end{array}$ & & $\begin{array}{l}\text { Students return to their original teams and exchange with one another on the discussion result in step } 2 . \\
\text { Then, they are supposed to write presentation script. }\end{array}$ \\
\hline
\end{tabular}


3) Assessing: assessment is made through 3 dimension: peer evaluation within team, peer evaluation across teams and the teacher's assessment.

TABLE III ASSESSING

\begin{tabular}{|l|l|}
\hline Step & Details \\
\hline $\begin{array}{l}\text { Step 1 } \\
\text { Submit } \\
\text { Task } \\
\text { Output via } \\
\text { SPOC } \\
\text { Platform }\end{array}$ & $\begin{array}{l}\text { Each team submit their task outputs, including the emails and the phone call records, to SPOC platform. Then, they are } \\
\text { required to make peer evaluation both within team and across teams according to the rubrics given by the teacher. }\end{array}$ \\
\hline $\begin{array}{l}\text { Step 2 } \\
\text { Assessment } \\
\text { and Test }\end{array}$ & $\begin{array}{l}\text { The teacher make assessment based on the outputs submitted by each team and chooses typical examples of A, C and } \\
\text { The teacher will make in-class comment on the examples she/he has chosen, and give revising suggestion to each team. } \\
\text { Students will take a test on listening, reading and wiring based on what they have learned in this unit. }\end{array}$ \\
\hline $\begin{array}{l}\text { Step 3 } \\
\text { Make-up } \\
\text { Learning }\end{array}$ & $\begin{array}{l}\text { Each team is supposed to revise their outputs after class. } \\
\text { Students who get poor score in test are supposed to do make-up learning tasks via SPOC platform. }\end{array}$ \\
\hline
\end{tabular}

\section{Feedback and Teaching Effect}

The teaching practice of Integrated Business English Coursed based on POA and SPOC mode has been made for almost one year, in Dalian Neusosft University of Information. In order to collect the feedback from students, the author designed a questionnaire. All the questions in this questionnaire are about 3 perspectives: evaluation on one's personal performance in this course, evaluation on the online materials offered by the SPOC platform and evaluation on the teaching procedure design. The data shows, most students (78\%) believe they have made progress in language proficiency, business and culture knowledge. Most students (90\%) agree the online materials of SPOC platform are of great help in self-learning.
$72 \%$ of the students believe the current teaching design can motivate their learning interest and passion, but $27 \%$ of the students show their anxiety about the difficulty degree of the motivating tasks.

In order to collect the feedback from teachers, the author also organizes a seminar among all the teachers who teach the same course. For the advantages of this new teaching design, all the teachers agree that students perform more actively than before and the SPOC platform sets teachers free from mechanical language usage instruction. But teachers also agree that this new design raised more challenges in teaching activities design, especially the motivating task design, and online material making.

\section{CASEC Test Score}

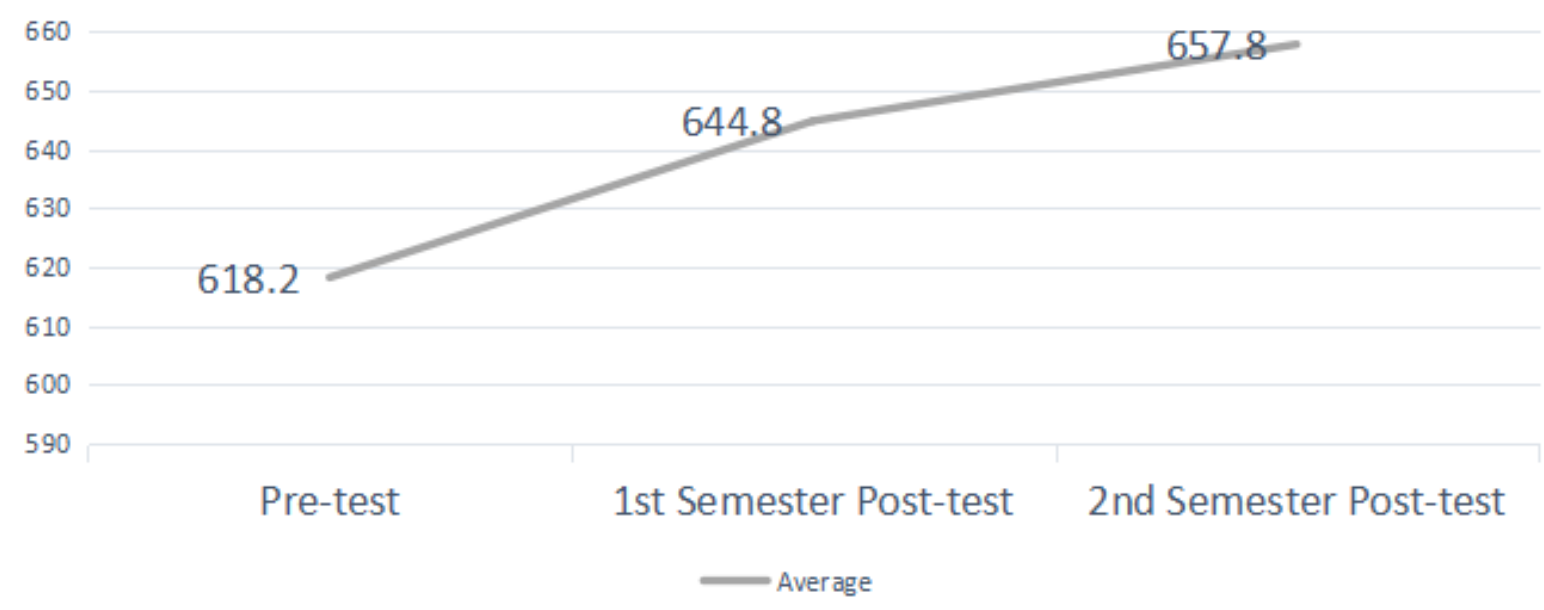

Fig. 2 CASEC Test Score 
The pre-test and post-test through a third party test CASEC (computerized Assessment System for English Communication) shows, students made obvious improvement in English communication abilities.

\section{CONCLUSION}

In recent years, scholars of foreign language teaching have made great process in POA and SPOC learning mode. Their explorations and experiences encourage the author to make a bold move to apply both POA and SPOC mode into ESP teaching, seeking for dual effects.

Due to various reasons, the current teaching design of Integrated Business English Course still needs revision in details; and the online materials and motivating tasks is scheduled to be revised in the following year. The author wishes this paper could offer some references to teachers who are interested in either POA or SPOC mode. In addition, the author also expect more and more foreign language teachers could participate in the practice of POA based on SPOC mode.

\section{REFERENCES}

[1] Wen Qiufang, "Developing a Theoretical System of Production-oriented Approach in Language Teaching," in Foreign Language Teaching and Research, vol 4, Beijing, 2015, pp387-398. (In Chinese)

[2] Zhang Zhou, "A Probe into an "Internet +"-Based EOP Teaching Mode for Vocational Colleges," in Technology Enhanced Foreign Language Education, vol 2, Shanghai, 2016, pp75-77. (In Chinese)

[3] Zhang Wenjuan, "Applying Production-oriented Approach to College English Classrooms: A Teaching Experiment," in Foreign Languages and Their Teaching, vol 2, Dalian, 2016, pp106-114. (In Chinese)

[4] Wen Qiufang, "Output-driven-input Enabled Hypothesis: Developing a College Foreign Language Teaching Theory," in Foreign Language Education in China, vol 2, Beijing, 2014, pp3-12. (In Chinese) 